\title{
PENGARUH PAPARAN MEDAN MAGNET EXTREMELY LOW FREQUENCY (ELF) TERHADAP PH DAN DAYA HANTAR LISTRIK PADA PROSES FERMENTASI BASAH KOPI LIBERIKA (Coffea liberica) DENGAN PENAMBAHAN $\alpha$-AMILASE
}

\author{
Nanda Rizky Fitrian Kanza' ${ }^{1}$, Sudarti ${ }^{1}$, Maryani ${ }^{1)}$ \\ 1)Program Studi Pendidikan Fisika, FKIP, Universitas Jember, Jember, Jawa Timur, Indonesia \\ Corresponding author : Nanda Rizky Fitrian Kanza \\ E-mail : nandarizkyfitriankanza@gmail.com
}

Diterima 28 Oktober 2020, Direvisi 07 November 2020, Disetujui 08 November 2020

\begin{abstract}
ABSTRAK
Penelitian ini bertujuan untuk mengkaji pengaruh paparan medan magnet Extremely Low Frequency (ELF) terhadap $\mathrm{pH}$ dan daya hantar listrik pada proses fermentasi basah kopi liberika dengan penambahan $\alpha$-amilase. Jenis penelitian ini merupakan penelitian eksperimen dengan randomized subjects post test only control group design. Pada penelitian ini terdapat 7 perlakuan yang terdiri dari kelompok kontrol dan kelompok eksprimen yang dipapar medan magnet ELF dengan variasi intensitas $300 \mu \mathrm{T}$ dan $400 \mu \mathrm{T}$ dan variasi lama paparan 30 menit, 60 menit, dan 90 menit. Pengambilan data dilakukan pada jam ke-24, jam ke-48, hari ke-3, hari ke-4, dan hari ke-5 setelah proses fermentasi. Hasil penelitian menunjukkan bahwa paparan medan magnet Extremely Low Frequency (ELF) berpengaruh terhadap $\mathrm{pH}$ dan daya hantar listrik pada proses fermentasi basah kopi liberika dengan penambahan $\alpha$ amilase yang ditunjukkan dengan bervariasinya grafik. Pengukuran kopi liberika dengan paparan medan magnet ELF intensitas $400 \mu \mathrm{T}$ selama 30 menit paling berpengaruh terhadap pH kopi liberika. Sedangkan, pengukuran kopi liberika dengan paparan medan magnet ELF intensitas $300 \mu \mathrm{T}$ selama 30 menit dan 90 menit paling berpengaruh terhadap daya hantar listrik kopi liberika yang telah difermentasi secara basah dengan penambahan $\alpha$-amilase.
\end{abstract}

Kata kunci: medan magnet ELF; pH; daya hantar listrik; fermentasi; kopi.

\begin{abstract}
The purpose of the research is to examine the effect of Extremely Low Frequency (ELF) magnetic field to $\mathrm{pH}$ and electrical conductivity in the wet fermentation process of liberica coffee with the addition of $\alpha$ amylase. Type of the research is an experimental research with randomized subjects post test only control group design. There is seven treatments consist of control group and experimental group exposed to ELF magnetic field with $300 \mu \mathrm{T}$ and $400 \mu \mathrm{T}$ intensity variation and for 30,60 , and 90 minutes for long variations. For hours 24,48 , day 3 , day 4 , and day 5 , can make data retrieval after fermentation process. The result explain is effect of Extremely Low Frequency (ELF) magnetic field to $\mathrm{pH}$ and electrical conductivity in the wet fermentation process of liberica coffee with the addition of $\alpha$-amylase was take effect to indicated by the variation of the graph. The process ELF magnetic field with $400 \mu \mathrm{T}$ intensity for 30 minutes most influential on $\mathrm{pH}$ of liberica coffee. Meanwhile, the process ELF magnetic field with $300 \mu$ T intensity for 30 and 90 minutes most influential on electrical conductivity of liberica coffee in the wet fermentation with the addition of $\alpha$-amylase.
\end{abstract}

Keywords: ELF magnetic field; $\mathrm{pH}$; electrical conductivity; fermentation; coffee.

\section{PENDAHULUAN}

Pesatnya perkembangan teknologi membuat penggunaan alat elektronik dalam kehidupan sehari-hari semakin meningkat. Setiap peralatan elektronik menghasilkan medan magnet ketika dialiri arus listrik. Gelombang elektromagnetik merupakan gelombang yang terdiri dari medan listrik dan medan magnet yang berisolasi dan membawa energi dari satu tempat ke tempat yang lain tanpa memerlukan media rambat. Radiasi yang dipancarkan oleh gelombang elektromagnetik dikelompokkan berdasarkan panjang gelombang dan frekuensinya.

Gelombang elektromagnetik Extremely

Low Frequency (ELF) adalah gelombang elektromagnetik yang memiliki frekuensi sangat rendah yaitu antara 0 hingga $300 \mathrm{~Hz}$ (Muharromah et al., 2018). Medan magnet dan medan listrik adalah komponen gelombang elektromagnetik yang memiliki kararkteristik berbeda. Medan magnet mampu menembus 
hampir semua material, sedangkan medan listrik tidak mampu melakukan hal tersebut (Sudarti et al., 2018). Selain itu, medan magnet ELF bersifat tidak terhalangi. Medan magnet ELF yang mampu menembus hampir semua bahan memberikan efek tidak terjadinya proses ionisasi, sehingga medan magnet ELF termasuk radiasi bukan pengion. Energi medan magnet yang sangat kecil menghasilkan efek non termal pada target biologis, artinya tidak menyebabkan perubahan suhu ketika berinteraksi atau menginduksi sistem (Agustina et al., 2018). Karakteristik inilah yang memungkinkan medan magnet memiliki manfaat yang sangat besar.

Penelitian dengan memanfaatkan radiasi gelombang elektromagnetik ELF dalam berbagai bidang mulai dilakukan, salah satunya dalam bidang pangan. Beberapa penelitian terkait dengan hal tersebut diantaranya Ridawati (2017) menyatakan, bahwa paparan medan magnet ELF dengan intensitas $300 \mu \mathrm{T}$ dan lama paparan 5 menit memberikan pengaruh terhadap nilai $\mathrm{pH}$ dan $\mathrm{DHL}$ pada susu fermentasi. Paparan medan magnet ELF dengan intensitas $300 \mu \mathrm{T}$ dan $500 \mu \mathrm{T}$ berpengaruh terhadap perubahan jumlah mikroba dan $\mathrm{pH}$ pada proses fermentasi tape ketan (Sadidah et al., 2015). Paparan medan magnet ELF intensitas $300 \mu \mathrm{T}$ dan $500 \mu \mathrm{T}$ dengan lama paparan 30 menit mampu mempertahankan $\mathrm{pH}$ pada buah tomat (Ma'rufiyanti et al., 2014). Selain itu, Dewi (2019) menyebutkan paparan medan magnet ELF intensitas $100 \mu \mathrm{T}$ dan lama paparan 90 menit berpengaruh terhadap nilai $\mathrm{pH}$ dan $\mathrm{DHL}$ biji kakao kering pada proses fermentasi. Dengan adanya penelitian-penelitian tersebut, pengkajian tentang pengaruh paparan medan magnet ELF terhadap peningkatan teknologi pengolahan pangan dapat dilakukan seperti pada proses fermentasi. Salah satu proses fermentasi terjadi pada biji kopi. Penanganan yang tepat pada kopi berpeluang dalam meningkatkan kualitas kopi (Sulistyaningtyas, 2017).

Kopi merupakan salah satu jenis tanaman perkebunan dan menjadi komoditi hasil perkebunan untuk diekspor karena memiliki nilai ekonomis yang cukup tinggi. Berbagai jenis kopi telah dibudidayakan di Indonesia, salah satunya adalah kopi liberika. Kopi liberika termasuk kopi yang kurang komersil di Indonesia karena variasi bentuk ukuran biji dan kualitas citarasa kopi yang tidak sebaik kopi arabika serta penyusutan bobot pascapanen yang cukup tinggi. Namun, kopi liberika mulai disukai karena citarasanya. Karakteristik rasa kopi liberika tidak sepahit kopi robusta, ada aroma nangka asam mirip kopi arabika dan coklat (Prasetyo et al., 2019). Kopi liberika juga disebut sebagai kopi nangka karena memiliki aroma seperti buah nangka ketika sudah diseduh.

Kopi memiliki banyak kandungan bakteri yang dapat digunakan dalam proses fermentasi. Proses fermentasi basah akan menghasilkan citarasa dan aroma yang lebih baik dari pengolahan kering yaitu menghilangkan rasa pahit, memberikan kekentalan, menimbulkan keasaman yang baik dan kesan mild pada seduhan kopi (Yusianto \& Widyotomo, 2013). Fermentasi menggunakan bantuan mikroba akan menghasilkan kopi dengan citarasa dan aroma yang khas, tetapi fermentasi yang seperti ini tidak dapat berjalan secara optimal dalam proses pemecahan gula pada fermentasi kopi (Astutik, 2017). Solusii yang dapat membantu proses pemecahan pati pulp pada biji kopi adalah menambahkan enzim $\alpha$-amilase. Penambahan $\alpha$-amilase mampu bertindak sebagai katalis untuk menghidrolisis komponen pati pulp kopi, sehingga mengoptimalkan kerja mikroba selama fermentasi (Fauzi et al., 2017).

Kopi berkaitan erat dengan tingkat keasaman (pH). Firdaus et al. (2018) menjelaskan, kopi dengan tingkat keasaman yang baik adalah kopi yang manis, enak, dan kesegarannya seperti buah segar saat baru diseruput. Dengan penambahan $\alpha$-amilase pada kopi akan memberikan pengaruh keasaman yang lebih baik. $\alpha$-amilase akan mengoptimalkan pemecahan karbohidrat pada kopi, sehingga bakteri asam laktat menjadi lebih cepat dalam menggunakan glukosa sebagai substrat. Hasil penelitian Fauzi et al. (2017) menyatakan, bahwa penambahan enzim $\alpha$ amilase pada fermentasi kopi luwak robusta artifisial berpengaruh pada peningkatan total asam tertitrasi yang terjadi karena pembentukan asam-asam organik hasil degredasi gula oleh mikroba.

Paparan medan magnet ELF dapat meningkatkan aktivitas enzim $\alpha$-amilase karena adanya perubahan kadar ion kalsium (Handoko et al., 2017). Penelitian Afzal et al. (2012) menyatakan, bahwa paparan medan magnet $100 \mathrm{mT}$ selama 3 menit pada biji marigold memberikan performa aktivitas $\alpha$-amilase maksimum. Perbaikan kualitas kopi liberika dengan menggunakan metode yang lebih unggul perlu dilakukan. Penggunaan paparan medan magnet Extremely Low Frequency (ELF) pada proses fermentasi basah kopi liberika dengan penambahan enzim $\alpha$-amilase menggunakan intensitas dan lama paparan yang sesuai dapat menjadi alternatifnya. 


\section{METODE PENELITIAN}

Penelitian ini merupakan jenis penelitian eksperimen yang dilakukan dengan cara membandingkan dua kelompok yaitu kelompok kontrol dan kelompok eksperimen. Desain penelitian yang digunakan adalah randomized subjects post test only control group design untuk mengetahui pengaruh dari beberapa perlakuan yang diberikan dengan melakukan pengulangan beberapa percobaan.

Bahan yang digunakan dalam penelitian ini meliputi kopi liberika yang diperoleh dari Kabupaten Banyuwangi, enzim $\alpha$-amilase, dan aquades. Penelitian diawali dengan persiapan pembuatan sampel. Pembuatan sampel dimulai dengan memetik buah kopi jenis liberika yang selanjutnya disortasi dengan tujuan untuk memisahkan buah dari kotoran, ranting daun, dan biji kopi yang cacat (Wulandari, 2016). Kopi liberika yang telah disortir kemudian dipulping agar diperoleh biji kopi liberika terbungkus kulit tanduk yang masih terdapat lendir. Lalu, biji kopi liberika yang telah dipulping dibagi secara rata ke dalam 7 bak yang berukuran diameter $21 \mathrm{~cm}$ dan tinggi 19,5 cm. Selanjutnya, biji kopi liberika difermentasi secara basah dengan penambahan aquades 0,5 liter $/ 0,7 \mathrm{~kg}$ biji kopi dan enzim $\alpha$-amilase sebesar $10 \mathrm{ml} / \mathrm{kg}$. Proses fermentasi dilakukan dengan lima variasi yaitu jam ke-24, jam ke-48, hari ke-3, hari ke-4, dan hari ke-5. Kopi liberika dibagi menjadi kelompok kontrol dan kelompok eksperimen. Kelompok kontrol tidak diberi perlakuan pemaparan medan magnet ELF, sedangkan kelompok eksperimen diberi perlakuan pemaparan medan magnet ELF yang terdiri dari enam perlakuan yaitu intensitas medan magnet ELF $300 \mu \mathrm{T}$ dan $400 \mu \mathrm{T}$ dengan masing-masing lama paparan 30 menit, 60 menit, dan 90 menit. Pada penelitian ini dilakukan lima kali pengulangan di setiap kelompok perlakuan. Sebelum pemaparan, sampel terlebih dahulu diukur $\mathrm{pH}$ dan daya hantar listrik awal kopi liberika. Setelah pemaparan, kopi liberika diukur $\mathrm{pH}$ dan daya hantar listriknya pada jam ke-24, jam ke-48, hari ke-3, hari ke-4, dan hari ke- 5 setelah proses fermentasi. Pengukuran $\mathrm{pH}$ dan daya hantar listrik dilakukan dengan mengambil $20 \mathrm{ml}$ cairan kopi per sampel.

Adapun sumber medan magnet ELF berupa CT (Current Transformer) untuk menghasilkan medan magnet ELF dengan sumber arus AC pada frekuensi $50 \mathrm{~Hz}$ dari PLN yang terdiri dari transformer tegangan, transformator arus masing-masing 100/5 A, 300/5 A, dan 600/5 A, pengatur tegangan, amperemeter, serta batang konduktor yang terbuat dari tembaga dengan diameter masingmasing $3 \mathrm{~cm}$. Kemudian, EMF tester tipe Lutron
EMF-827 sebagai alat pengukur besar medan magnet yang dihasilkan dari alat CT.

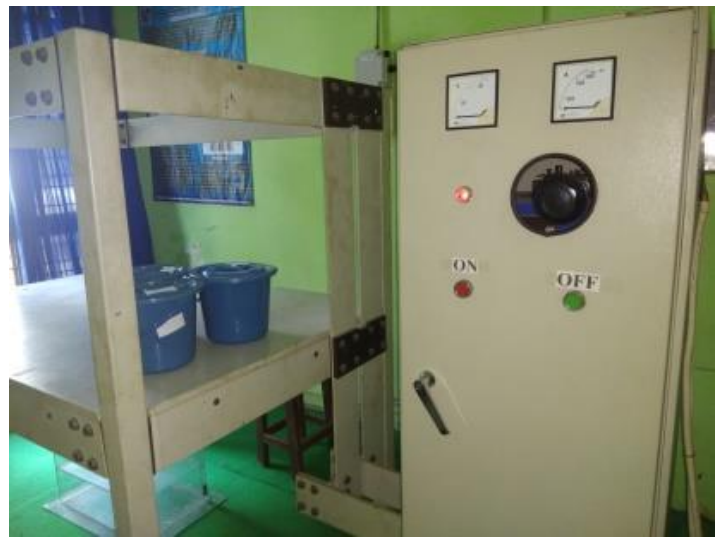

Gambar 1. Current Transformer

Selain itu, untuk uji $\mathrm{pH}$ kopi liberika menggunakan $\mathrm{pH}$ meter yang sebelumnya telah dikalibrasi dengan buffer $\mathrm{pH} 7$ dan uji daya hantar listrik kopi liberika menggunakan TDS \& EC meter.

Teknik analisa data pada penelitian ini menggunakan SPSS 23 dengan uji Independen sampel t-test - Mann Whitney yang berfungsi untuk menguji ada atau tidak perbedaan ratarata dari dua sampel yang tidak berpasangan. Kemudian, dilanjutkan dengan uji KruskalWallis sebagai pengganti uji One Way Anova yang berfungsi untuk menguji ada atau tidak perbedaan dari tiga atau lebih sampel yang tidak berpasangan (Suyanto \& Gio, 2017).

\section{HASIL DAN PEMBAHASAN}

Penelitian ini bertujuan untuk mengkaji pengaruh paparan medan magnet ELF terhadap $\mathrm{pH}$ dan daya hantar listrik pada proses fermentasi basah kopi liberika dengan penambahan $\alpha$-amilase. Penelitian ini dilaksanakan di Laboratorium ELF Program Studi Pendidikan Fisika FKIP Universitas Jember sebagai tempat pemaparan medan magnet ELF dan Laboratorium Mikrobiologi Program Studi Pendidikan Biologi FKIP Universitas Jember sebagai tempat pengukuran $\mathrm{pH}$ dan daya hantar listrik dari sampel penelitian.

\section{pH Kopi Liberika}

Pengukuran $\mathrm{pH}$ kopi liberika pada kelompok kontrol dan kelompok eksperimen diperoleh hasil yang berbeda antara kelompok kontrol dan kelompok eksperimen yang disebabkan karena perbedaan perlakuan pemaparan medan magnet ELF yang diberikan. Data pengukuran $\mathrm{pH}$ kopi liberika disajikan pada gambar berikut. 


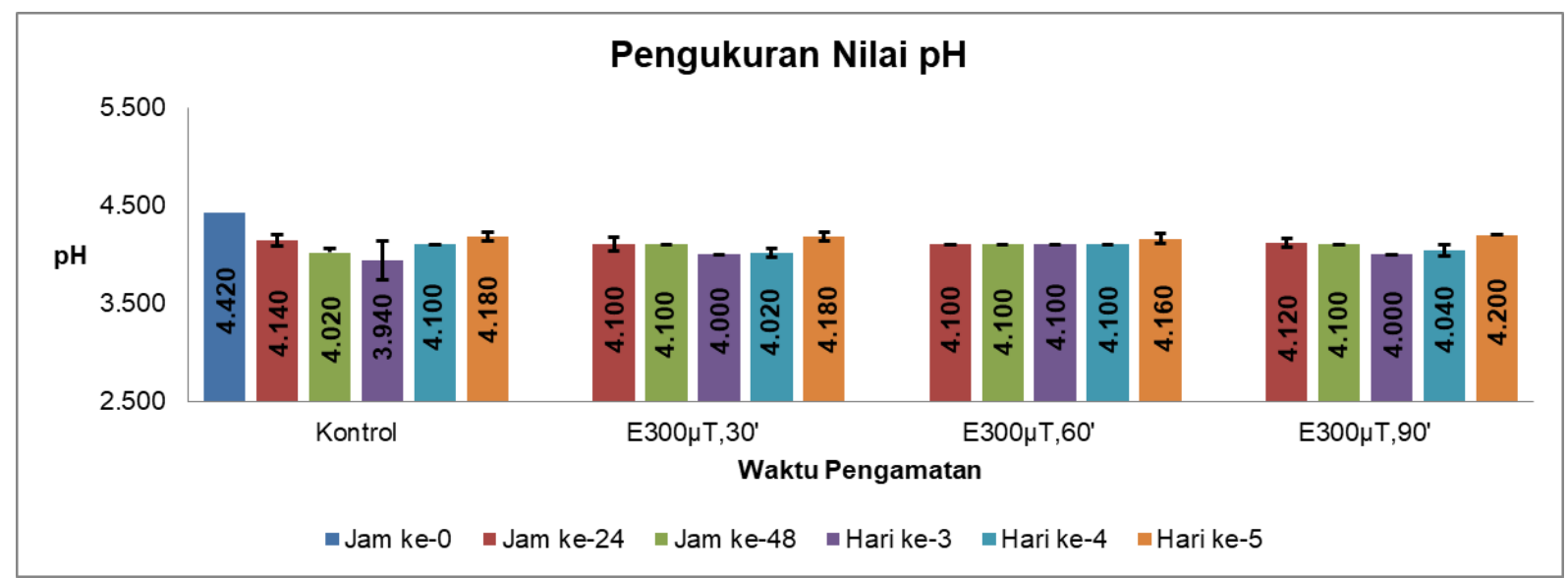

Gambar 2. Diagram Pengukuran Nilai pH Kopi Liberika Intensitas $300 \mu \mathrm{T}$

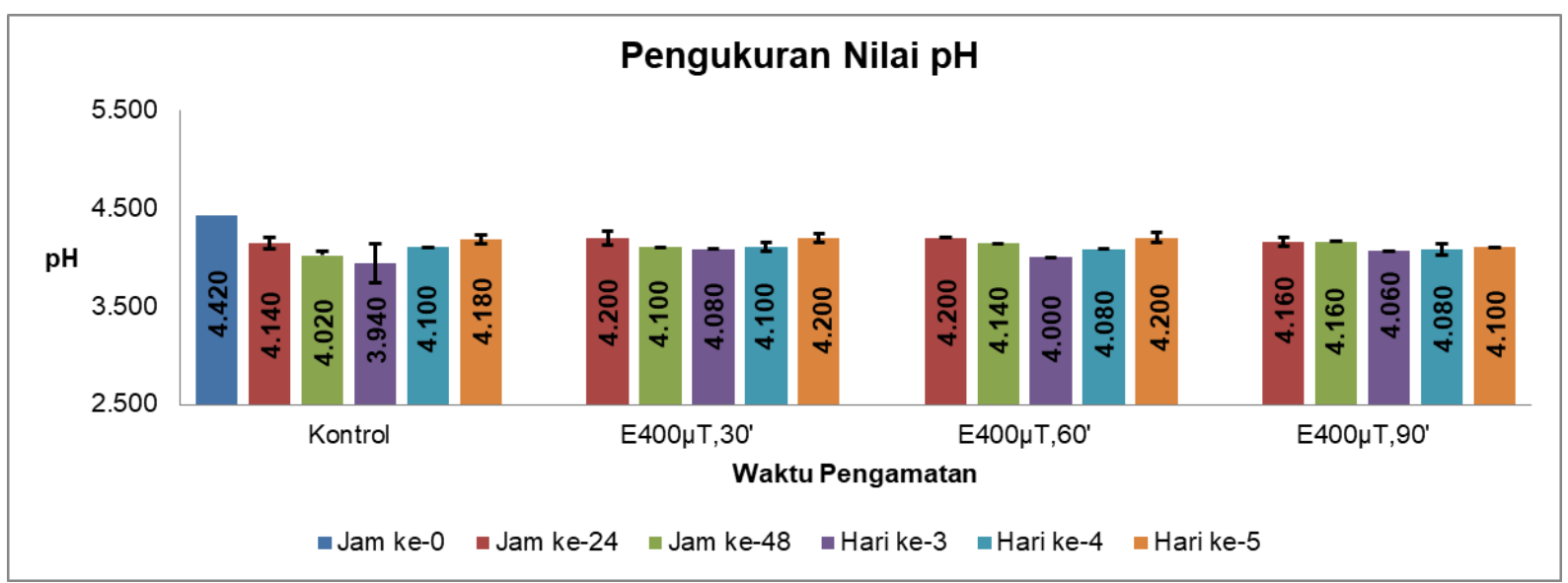

Gambar 3. Diagram Pengukuran Nilai pH Kopi Liberika Intensitas $400 \mu \mathrm{T}$

Berdasarkan gambar 2 dan 3, pH kopi liberika pada kelompok kontrol dan kelompok eksperimen memiliki bentuk grafik yang bervariasi. Pada jam ke-0 (sebelum pemaparan) $\mathrm{pH}$ memiliki nilai sebesar 4,420. Selanjutnya, pada kelompok kontrol yang lain yaitu jam ke-24 sampai hari ke-3 nilai $\mathrm{pH}$ mengalami penurunan, dan pada hari ke-4 menuju hari ke-5 mengalami peningkatan. Pada kelompok eksperimen, nilai $\mathrm{pH}$ yang berada di bawah kelompok kontrol terdapat pada kelompok eksperimen (300 $\mu \mathrm{T}, 30$ '; 300 $\mu \mathrm{T}, 60^{\prime} ; 300 \mu \mathrm{T}, 90^{\prime} ; 400 \mu \mathrm{T}, 60$ '; $\left.400 \mu \mathrm{T}, 90^{\prime}\right)$. Sedangkan, nilai $\mathrm{pH}$ ada yang berada di atas kelompok kontrol yaitu pada kelompok eksperimen dengan medan magnet ELF intensitas $400 \mu \mathrm{T}$ dan lama paparan 30 menit. Peningkatan nilai $\mathrm{pH}$ kelompok eksperimen (400 $\mu \mathrm{T}, 30$ ') dapat dilihat dari grafik yang menunjukkan pada intensitas tersebut semuanya berada di atas kelompok kontrol yaitu jam ke-24 sebesar 4,200, jam ke-48 sebesar 4,100, hari ke-3 sebesar 4,080, hari ke4 sebesar 4,100, dan hari ke-5 sebesar 4,200.

Adanya peningkatan nilai $\mathrm{pH}$ pada kopi liberika terjadi karena paparan medan magnet ELF mempengaruhi pergerakan ion pada ekstraseluler yang melintasi membran sel, sehingga paparan medan magnet meningkatkan percepatan pergerakan ion. Bidang yang terpapar medan magnet akan menghasilkan kekuatan pada ion untuk bergerak dan secara aktif terikat pada saluran protein dan mempengaruhi kondisi pembukaan gerbang saluran pada membran sel (Ridawati, 2017). Ion dalam sel yang terpengaruh oleh medan magnet pada pertumbuhan sel yaitu ion kalsium $\left(\mathrm{Ca}^{2+}\right)$. Ion kalsium $\left(\mathrm{Ca}^{2+}\right)$ tergolong bahan yang bersifat paramagnetik, oleh karena itu ion kalsium dapat terpengaruh oleh medan magnet. Bentuk pengaruh medan magnet terhadap bahan tersebut yaitu spin elektron yang terdapat pada bahan yang mulanya acak menjadi terarah oleh medan magnet (Sutrisno \& Gie, 1979). Kecepatan arah pergerakan ion kalsium $\left(\mathrm{Ca}^{2+}\right)$ ekstraseluler yang melewati membran sel dapat berubah karena adanya arus induksi yang ditimbulkan oleh perubahan medan magnet. Sehingga, jika pemenuhan kebutuhan ion kalsium $\left(\mathrm{Ca}^{2+}\right)$ terjaga sesuai dengan kebutuhan sel, maka akan mempercepat pertumbuhan sel dan bakteri menjadi semakin banyak. Sedangkan, jika ion kalsium $\left(\mathrm{Ca}^{2+}\right)$ yang masuk ke dalam sel kurang atau lebih dari jumlah yang dibutuhkan oleh sel maka pertumbuhan sel akan terhambat bahkan 
terjadi kerusakan pada sel.

Berdasarkan data yang diperoleh, menunjukkan bahwa medan magnet ELF berpengaruh terhadap nilai $\mathrm{pH}$ kopi liberika. Hal ini ditunjukkan pada pengukuran $\mathrm{pH}$ menggunakan intensitas $400 \mu \mathrm{T}$ selama 30 menit. Pada intensitas tersebut medan magnet mampu mempengaruhi pertumbuhan sel dan mempercepat aktivitas $\alpha$-amilase dalam memecah pati pulp pada kopi liberika agar bakteri asam laktat menjadi lebih cepat menggunakan glukosa sebagai substrat, sehingga kerja mikroba selama proses fermentasi menjadi optimal. Paparan medan magnet ELF memberikan hasil yang baik dan tingkat keasaman yang tepat pada proses fermentasi basah kopi liberika dengan penambahan $\alpha$-amilase. Dengan demikian, paparan medan magnet ELF intensitas $400 \mu \mathrm{T}$ berpengaruh terhadap nilai $\mathrm{pH}$ kopi liberika yang telah difermentasi secara basah dengan penambahan $\alpha$-amilase.

\section{Daya Hantar Listrik Kopi Liberika}

Pengukuran daya hantar listrik kopi liberika pada kelompok kontrol dan kelompok eksperimen diperoleh hasil yang berbeda antara kelompok kontrol dan kelompok eksperimen yang disebabkan karena adanya perbedaan perlakuan pemaparan medan magnet ELF yang diberikan. Data pengukuran daya hantar listrik kopi liberika disajikan pada gambar berikut.

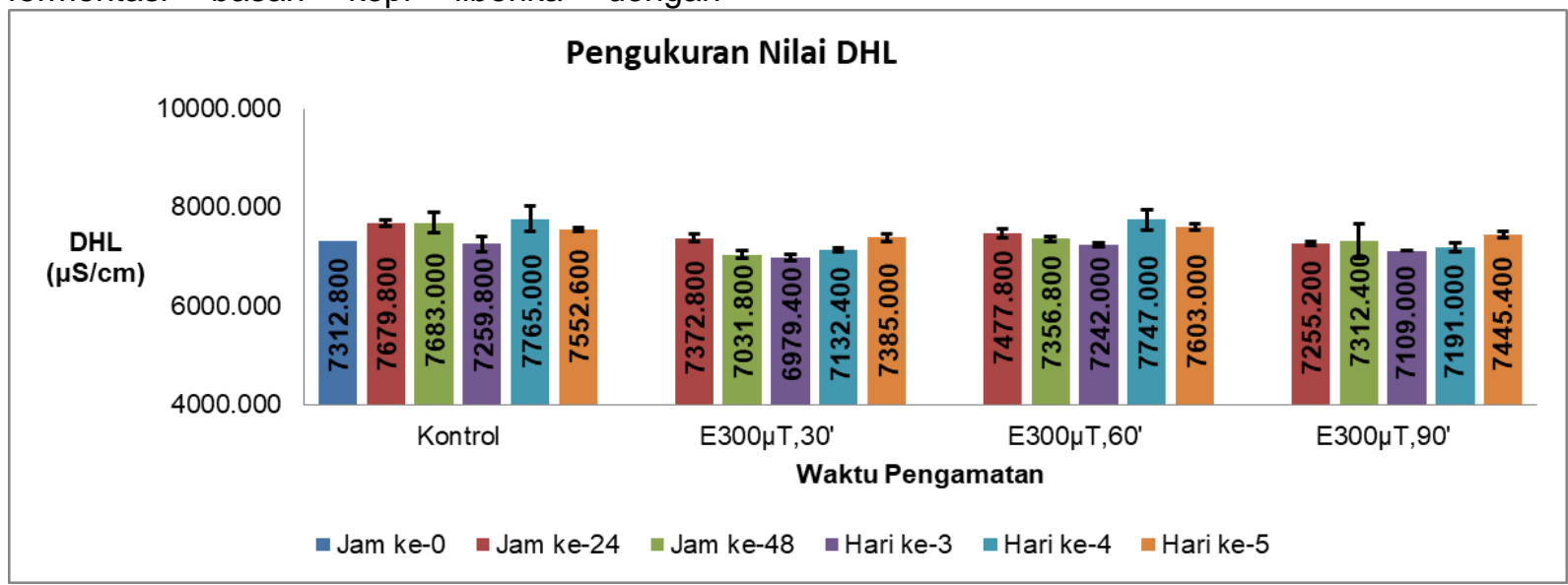

Gambar 4. Diagram Pengukuran Nilai Daya Hantar Listrik Kopi Liberika Intensitas $300 \mu \mathrm{T}$

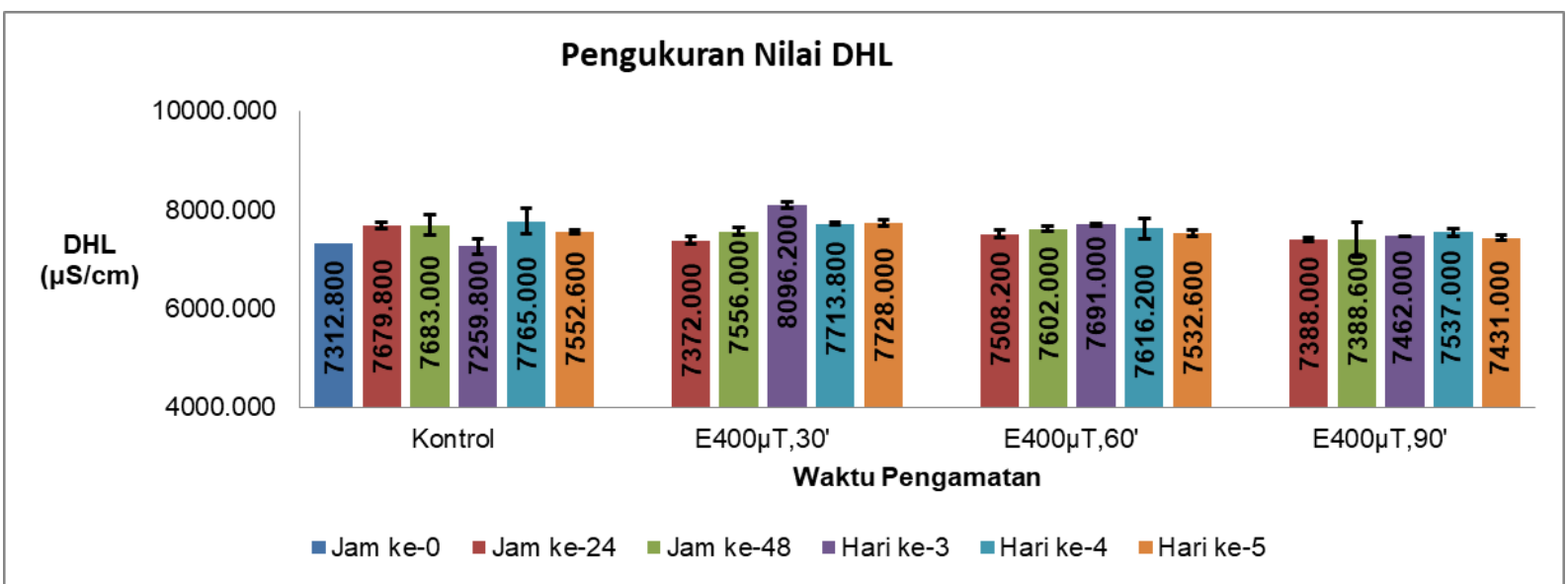

Gambar 5. Diagram Pengukuran Nilai Daya Hantar Listrik Kopi Liberika Intensitas $400 \mu \mathrm{T}$

Berdasarkan gambar 4 dan 5, daya hantar listrik (DHL) kopi liberika pada kelompok kontrol dan kelompok eksperimen memiliki bentuk grafik yang bervariasi. Pada jam ke-0 (sebelum pemaparan) nilai DHL sebesar $7312,800 \mu \mathrm{S} / \mathrm{cm}$. Selanjutnya, pada kelompok kontrol yang lain yaitu jam ke-24 dan jam ke-48 nilai DHL mengalami peningkatan yang selanjutnya pada hari ke-3 mengalami penurunan dan menuju hari ke-4 mengalami peningkatan, dilanjutkan dengan hari ke-5 yang mengalami penurunan. Pada kelompok eksperimen, nilai DHL yang berada di atas kelompok kontrol terdapat pada kelompok eksperimen (300 $\mu \mathrm{T}, 60$ '; $400 \mu \mathrm{T}, 30$ '; 400 $\mu \mathrm{T}, 60$ '; $\left.400 \mu \mathrm{T}, 90^{\prime}\right)$. Sedangkan, nilai DHL ada yang berada di bawah kelompok kontrol yaitu pada kelompok eksperimen dengan medan magnet ELF intensitas $300 \mu \mathrm{T}$ dan lama paparan 30 menit dan 90 menit. Penurunan 
nilai $\mathrm{DHL}$ pada kelompok eksperimen $(300 \mu \mathrm{T}$, 30 ' dan $300 \mu \mathrm{T}, 90$ ') dapat dilihat dari grafik yang menujukkan pada intensitas tersebut semuanya berada di bawah kelompok kontrol yaitu pada kelompok eksperimen (300 $\mu \mathrm{T}, 30$ ') jam ke-24 sebesar $7372,800 \mu \mathrm{S} / \mathrm{cm}$, jam ke-48 sebesar $7031,800 \mu \mathrm{S} / \mathrm{cm}$, hari ke-3 sebesar $6979,400 \mu \mathrm{S} / \mathrm{cm}$, hari ke-4 sebesar 7132,400 $\mu \mathrm{S} / \mathrm{cm}$, dan hari ke- 5 sebesar $7385,000 \mu \mathrm{S} / \mathrm{cm}$. Pada kelompok eksperimen (300 $\mu \mathrm{T}, 90$ ') jam ke-24 sebesar $7255,200 \mu \mathrm{S} / \mathrm{cm}$, jam ke-48 sebesar 7312,400 $\mu \mathrm{S} / \mathrm{cm}$, hari ke-3 sebesar $7109,000 \mu \mathrm{S} / \mathrm{cm}$, hari ke-4 sebesar 7191,000 $\mu \mathrm{S} / \mathrm{cm}$, dan hari ke-5 sebesar $7445,400 \mu \mathrm{S} / \mathrm{cm}$.

Daya hantar listrik merupakan ukuran seberapa kuat larutan dapat menghantarkan arus listrik. Daya hantar listrik berhubungan dengan pergerakan suatu ion di dalam larutan. Jika ion pada suatu larutan dapat dengan mudah bergerak, maka larutan tersebut memiliki daya hantar listrik yang besar (Khairiah \& Destini, 2017). Semakin asam suatu larutan, maka nilai pH akan semakin kecil. Sebaliknya, semakin lemah tingkat keasaman suatu larutan, maka nilai $\mathrm{pH}$ akan semakin besar. Oleh sebab itu, jika larutan elektrolit dengan tingkat keasaman yang tinggi atau $\mathrm{pH}$ kecil akan menghasilkan banyak ion, sehingga arus listrik yang dihasilkan juga semakin besar dan menyebabkan konduktivitas larutan elektrolit juga semakin besar. Namun, jika larutan elektrolit memiliki tingkat keasaman yang rendah atau $\mathrm{pH}$ besar, maka akan menghasilkan sedikit ion dan menyebabkan konduktivitas larutan elektrolit yang semakin kecil juga (Purnomo, 2010).

Medan magnet Extremely Low Frequency (ELF) dengan intensitas dan lama paparan tertentu dapat mempengaruhi laju ion yang menyebabkan pembentukan sel semakin cepat, sehingga aktivitas $\alpha$-amilase dan mikroba semakin optimal. Hal ini mempengaruhi pembentukan ion $\mathrm{H}^{+}$oleh bakteri asam laktat yang menyebabkan nilai daya hantar kelompok eksperimen lebih rendah dari kelompok kontrol. Namun, di waktu tertentu ion $\mathrm{H}^{+}$dapat berubah karena aktivitas $\alpha$ amilase dan bakteri asam laktat yang menyebabkan keasaman semakin meningkat dan daya hantar listrik semakin tinggi.

Berdasarkan data yang diperoleh, menunjukkan bahwa medan magnet ELF berpengaruh terhadap nilai daya hantar listrik kopi liberika. Hal ini ditunjukkan pada pengukuran daya hantar listrik menggunakan intensitas $300 \mu \mathrm{T}$ selama 30 menit dan 90 menit. Pada intensitas tersebut ion $\mathrm{H}^{+}$berhasil dikendalikan oleh aktivitas $\alpha$-amilase dan bakteri asam laktat pada proses fermentasi kopi liberika. Dengan demikian, paparan medan magnet ELF dengan intensitas $300 \mu T$ berpengaruh terhadap nilai daya hantar listrik kopi liberika yang telah difermentasi secara basah dengan penambahan $\alpha$-amilase.

\section{SIMPULAN DAN SARAN}

Berdasarkan hasil penelitian dapat disimpulkan bahwa paparan medan magnet Extremely Low Frequency (ELF) berpengaruh terhadap nilai $\mathrm{pH}$ dan nilai daya hantar listrik pada proses fermentasi basah kopi liberika dengan penambahan $\alpha$-amilase yang ditunjukkan dengan bervariasinya grafik.

Berdasarkan hasil penelitian dan pembahasan, maka saran yang diberikan yaitu perlu dilakukan penelitian lebih lanjut dengan intensitas dan lama paparan medan magnet ELF yang berbeda serta tentang proses fermentasi pada kopi liberika.

\section{UCAPAN TERIMAKASIH}

Peneliti mengucapkan terimakasih kepada Dr. Sudarti, M.Kes. dan Drs. Maryani, M.Pd. atas saran yang diberikan selama ini serta berbagai pihak yang telah mendukung.

\section{DAFTAR RUJUKAN}

Afzal, I., Mukhtar, K., Qasim, M., Basra, S. M. A., Shahid, M., \& Haq, Z. (2012). Magnetic stimulation of marigold seed. International Agrophysics, 26, 335-339.

Agustina, S. D., Prastowo, S. H. B., \& Sudarti. (2018). Analisis Intensitas Medan Magnet Extremely Low Frequency (ELF) di Sekitar Laptop. Jurnal Pembelajaran Fisika, 7(3), 286-292.

Astutik, Y. D. P. (2017). Karakterisasi Kimia Kopi Luwak Robusta Artifisial dengan Penambahan Enzim a-Amilase Selama Fermentasi. Universitas Jember.

Dewi, F. P. (2019). Pengaruh Paparan Medan Magnet Extremely Low Frquency (ELF) terhadap $\mathrm{pH}$ dan Daya Hantar Listrik (DHL) pada Proses Fermentasi Biji Kakao Kering. Universitas Jember.

Fauzi, M., Choiron, M., \& Astutik, Y. D. P. (2017) Karakteristik Kimia Kopi Luwak Robusta Artifisial Terfermentasi oleh Ragi Luwak dan A-Amilase. Jurnal Penelitian Pascapanen Pertanian, 14(3), 144-153.

Firdaus, M. A., Jayus, \& Suwasono. (2018). Mutu Dan Citarasa Kopi Arabika (Coffea Arabica L.) Terfermentasi secara Metode Basah dengan Penambahan a-Amilase. Berkala Ilmiah Pertanian.

Handoko, Sudarti, \& Handayani, R. D. (2017). Analisis Dampak Paparan Medan Magnet Extremely Low Frequency (ELF) pada Biji Cabai Merah Besar (Capsicum annum.L) terhadap Pertumbuhan Tanaman Cabai 
Merah Besar (Capsicum annum.L). Jurnal Pembelajaran Fisika, 5(4), 370-377.

Khairiah, \& Destini, R. (2017). Analysis of Effect of Yeast Mass Addition anda Fermentation Time to the Voltage of Durian (Durio Zibethinus) Husk Waste Paste. FISITEK: Jurnal IImu Fisika Dan Teknologi, 1(2), 16-22.

Ma'rufiyanti, P., Sudarti, \& Gani, A. A. (2014). Pengaruh Paparan Medan Magnet ELF (Extremely Low Frequency) $300 \mu \mathrm{T}$ dan $500 \mu \mathrm{T}$ terhadap Perubahan Kadar Vitamin $\mathrm{C}$ dan Derajat Keasaman $(\mathrm{pH})$ pada Buah Tomat. Jurnal Pendidikan Fisika, 3(3), 277-284.

Muharromah, N. N. A., Sudarti, \& Subiki. (2018). Pengaruh Paparan Medan Magnet Extremely Low Frequency (ELF) terhadap Sifat Organoleptik dan $\mathrm{pH}$ Susu Sapi Segar. FKIP e-PROCEEDING, 3(2), 1318.

Prasetyo, P., Hidayat, R., Nyoto, \& Purnomo, H. (2019). Budidaya Kopi Liberika di Lahan Gambut. Center for International Forestry Research (CIFOR), 4.

Purnomo, H. (2010). Pengaruh Keasaman Buah Jeruk terhadap Konduktivitas Listrik. ORBITH, 6(2), 276-281.

Ridawati, S. (2017). Pengaruh Paparan Medan Magnet Extremely Low Frequency (ELF) terhadap $\mathrm{pH}$ dan Daya Hantar Listrik Minuman Susu Fermentasi sebagai Indikator Kadaluarsa. Universitas Jember.

Sadidah, K. R., Sudarti, \& Ghani, A. A. (2015). Pengaruh Paparan Medan Magnet ELF (Extremely Low Frequency) $300 \mu \mathrm{T}$ dan $500 \mu \mathrm{T}$ terhadap Perubahan Jumlah Mikroba dan $\mathrm{pH}$ pada Proses Fermentasi Tape Ketan. Jurnal Pendidikan Fisika, 4(1), 1-8.

Sudarti, Bektiarso, S., Prastowo, S. H. B., Fuad, F., \& Trisnawati, I. J. (2018). Radiation Potential of Extremely Low Frequency (ELF) Magnetic Field to Increase Tobacco Production. International Journal of Engineering and Technology (IJET), 10(6), 1633-1640.

Sulistyaningtyas, A. R. (2017). Pentingnya Pengolahan Basah (Wet Processing) Buah Kopi Robusta (Coffea robusta Lindl. Ex. De. Will) untuk Menurunkan Resiko Kecacatan Biji Hijau saat Grading Coffee. Prosiding Seminar Nasional Publikasi Hasil-Hasil Penelitian Dan Pengabdian Masyarakat, 90-94.

Sutrisno, \& Gie, T. I. (1979). Fisika Dasar: Listrik, Magnet dan Termofisika. Bandung: ITB.

Suyanto, \& Gio, P. U. (2017). Statistika Nonparametrik dengan SPSS, Minitab dan R. Medan: USU Press.
Wulandari, S. (2016). Citarasa dan Komponen Flavor Kopi Luwak Robusta In Vitro Akibat Perbedaan Konsentrasi Ragi dan Lama Fermentasi. Universitas Jember.

Yusianto, \& Widyotomo, S. (2013). Quality and Flavor Profiles of Arabica Coffee Processed by Some Fermentation Treatments: Temperature, Containers, and Fermentation Agents Addition. Pelita Perkebunan (a Coffee and Cocoa Research Journal), 29(3), 220-239. 